\title{
ANALISIS INDEKS KUALITAS TANAH LAHAN KERING PADA BERBAGAI PENGGUNAAN LAHAN DI DESA NGALANG, KECAMATAN GEDANGSARI, KABUPATEN GUNUNGKIDUL
}

\section{(ANALYSIS OF DRYLAND SOIL QUALITY INDEX IN VARIOUS LAND USES IN NGALANG VILLAGE, GEDANGSARI SUBDISTRICT, GUNUNGKIDUL DISTRICT)}

\author{
Arya Satrya Wicaksono ${ }^{1)}$, Susila Herlambang ${ }^{2)^{*}}$, dan Didi Saidi $^{2)}$ \\ ${ }^{1)}$ Prodi Agroteknologi, Universitas Pembangunan Nasional Veteran Yogyakarta \\ 2) Prodi Ilmu Tanah, Universitas Pembangunan Nasional Veteran Yogyakarta \\ ${ }^{*}$ Corresponding author E-mail: susilaherlambang@upnyk.ac.id
}

\begin{abstract}
Population growth increased by $1.3 \%$ annually (BPS, 2010). To balance population growth, it was necessary to use dryland to fill the population's need for food. Indonesia has a potential dry land area of 13.7 million ha which was still untapped. However, dryland has limiting factors: the limited availability of irrigation, plants often experiences nutrient deficiency, and low quality of the soils. This study aimed to (a) determine the soil quality index for various land uses and (b) determine the distribution of soil quality in various land uses in Ngalang Village, Gedangsari District, Gunungkidul Regency. The method used in this study was a survey method, with the method of sampling using purposive sampling and the classification of soil quality classes using Soil Quality Index (SQI) which was calculated using the Minimum Data Set method from Mausbach and Seybold (1998) and continued determination of soil quality criteria. The sample point was determined based on the Land Unit Map (LUM) made from the overlay of land use maps, soil type maps, and slope maps, in this study there were 8 location points, there were ( $\mathrm{TE}_{1}, \mathrm{TE}_{2}, \mathrm{TI}_{1}, \mathrm{TI}_{2}, \mathrm{SE}_{1}, \mathrm{SE}_{2}, \mathrm{SI}_{1}$, dan $\mathrm{SI}_{2}$ ). Soil properties observed included: bulk density, porosity, silt and clay content, $\mathrm{pH} \mathrm{H}_{2} \mathrm{O}$, slope, slope length, slope factor, organic $\mathrm{C}$ content, $\mathrm{N}$ total, availabel $\mathrm{P}$, and available $\mathrm{K}$. Based on the study's results, the poor criteria's quality covered an area of 63.05 ha or $9.85 \%$ of the area observed with an SQI value covering the land unit $\mathrm{TE}_{2}(0.380)$; medium criteria covering an area of 523.9 ha or $81.81 \%$ of the area observed was located in land units $\mathrm{TE}_{1}(0.441), \mathrm{TI}_{1}(0.586) \mathrm{TI}_{2}(0.583), \mathrm{SE}_{1}(0.462), \mathrm{SE}_{2}(0.477)$, and $\mathrm{SI}_{1}$ (0.552); And the good criteria 53.44 ha or $8.34 \%$ included $\mathrm{SI}_{2}(0.647)$ land units.
\end{abstract}

Keywords: dryland, land use, soils, sqi, soil quality

\begin{abstract}
ABSTRAK
Pertumbuhan penduduk meningkat $1,3 \%$ setiap tahunnya (BPS, 2010). Untuk mengimbangi pertumbuhan penduduk maka diperlukan pemanfaaatan lahan kering dalam memenuhi kebutuhan penduduk akan pangan. Indonesia memiliki luasan lahan kering potensial 13,7 juta ha yang masih belum dimanfaatkan. Namun, lahan kering memiliki faktor pembatas salah satunya kualitas tanah di lahan kering tergolong rendah. Penelitian ini bertujuan untuk (a) menentukan indeks kualitas tanah pada berbagai penggunaan lahan dan (b) mengetahui sebaran kualitas tanah pada berbagai penggunaan lahan di Desa Ngalang, Kecamatan Gedangsari, Kabupaten Gunungkidul. Kemudian dianalisis di laboratorium. Metode yang digunakan dalam
\end{abstract}


penelitian ini adalah metode survei, dengan metode pengambilan sampel menggunakan purposive sampling dan pengklasifikasian kelas kualitas tanah menggunakan IKT (Indeks Kualitas Tanah) yang dihitung menggunakan metode Minimum Data Set dari Mausbach dan Seybold (1998) dan dilanjutkan penentuan kriteria kualitas tanah. Titik sampel ditentukan berdasarkan Peta Satuan Lahan (PSL) yang dibuat dari overlay peta penggunaan lahan, peta jenis tanah, dan peta kemiringan lereng, pada penelitian ini terdapat 8 titik lokasi antara lain $\left(\mathrm{TE}_{1}, \mathrm{TE}_{2}, \mathrm{TI}_{1}, \mathrm{TI}_{2}, \mathrm{SE}_{1}, \mathrm{SE}_{2}, \mathrm{SI}_{1}\right.$, dan $\mathrm{SI}_{2}$ ). Parameter yang digunakan antara lain: Berat volume, porositas, kadar debu dan lempung tanah, $\mathrm{pH} \mathrm{H}_{2} \mathrm{O}$, kemiringan lereng, panjang lereng, faktor lereng, kadar $\mathrm{C}$ - organik, $\mathrm{N}$ - total, $\mathrm{P}$ - tersedia, dan $\mathrm{K}$ - tersedia tanah. Berdasarkan hasil penelitian didapatkan hasil kualitas kriteria buruk seluas 66,70 ha atau $11,17 \%$ dari areal yang diamati dengan nilai IKT meliputi satuan lahan $\mathrm{TE}_{2}(0,391)$; Kriteria sedang seluas 477,12 ha atau $79,89 \%$ dari areal yang diamati terletak meliputi satuan lahan $\mathrm{TE}_{1}(0,449), \mathrm{TI}_{1}(0,596) \mathrm{TI}_{2}$ $(0,590), \mathrm{SE}_{1}(0,477), \mathrm{SE}_{2}(0,490)$, dan $\mathrm{SI}_{1}(0,578)$; Dan kriteria baik seluas 59,41 ha atau $8,94 \%$ meliputi satuan lahan $\mathrm{SI}_{2}(0,659)$.

Kata kunci : ikt, kualitas tanah, lahan kering

\section{PENDAHULUAN}

Pertumbuhan penduduk Indonesia yang setiap tahunnya bertambah 1,3\% (BPS, 2010). Untuk mengimbangi peningkatan pertumbuhan penduduk maka diperlukan pemanfaatan lahan kering dalam memenuhi kebutuhan masyarakat Indonesia akan pangan. Lahan kering adalah lahan yang tidak memiliki fasilitas irigasi atau pengusahaan sawah dengan sistem tadah hujan (Notohadiprawiro, 1989). Sebagai aspek penting kehidupan, tanah memiliki berbagai fungsi untuk mendukung aktivitas organisme yang hidup diatasnya. Kapasitas suatu tanah dalam menjalankan fungsi dapat menggambarkan kualitas tanah secara langsung. Kualitas tanah diukur melalui pengamatan kondisi dinamis dari fungsi fungsi tanah. Keadaan topografi, sistem irigasi, maupun kesuburan tanah dapat mempengaruhi ingkat kualitas tanah. Kualitas tanah juga dapat meningkat maupun menurun tergantung dari penggunaan lahan dan pola pengolahannya. Terbatasnya salah satu fungsi tanah akan berdampak pada menurunnya tingkat kualitas tanah. Sehingga diperlukan pola pengelolaan tanah yang tepat guna meningkatkan kualitas tanah. Pengelolaan lahan kering perlu dilakukan untuk memperkuat pemenuhan kebutuhan pangan penduduk yang jumlahnya semakin meningkat sekaligus mendukung program pemerintah dalam ketahanan pangan nasional.

Desa Ngalang Kecamatan Gedangsari yang terletak di sebelah utara Kabupaten Gunungkidul, Yogyakarta dengan luasan total areal 1.481,7 ha. Desa Ngalang didominansi oleh tanah kering yakni sebesar 781,9 ha (BPS, 2017; Bappeda Gunungkidul, 2018). Pada sektor pertanian, penggunaan lahan di Desa Ngalang didominansi areal tegalan dan sawah tadah hujan. Dengan keadaan relief yang berbukit - bukit, sumber irigasi utama berasal dari air hujan, dan kesuburan tanah yang rendah. Keadaan mengindikasikan beberapa faktor pembatas pada fungsi tanah yang mengakibatkan kualitas tanah rendah. Kualitas tanah didefinisikan sebagai kapasitas tanah untuk berfungsi pada batas-batas ekosistem dalam mempertahankan produktivitas biologis, men- jaga kualitas lingkungan, dan me- ningkatkan kesehatan tanaman dan hewan (SSSA, 1997 dalam Karlen et al., 2008). Penggambaran kondisi tanah ditunjukan dengan kemampuan tanah dalam menjalankan berbagai macam fungsi, dimana untuk setiap fungsi terdapat beberapa indikator. Seybold et al., (1996) menuturkan bahwa 
pemilihan indikator yang bersifat temporer seperti kelembaban tanah, jenis tanaman yang dibudidayakan atau pengolahan tanah penggunaannya akan dihindari karena indikator tersebut hanya menggambarkan kondisi tanah dalam kurun waktu yang singkat. Langkah penting dalam penilaian kualitas tanah dengan mengidentifikasi kendala terkait dalam produksi tanaman. Kualitas tanah diukur berdasarkan pengamatan kondisi dinamis indikator-indikator kualitas tanah. Pengukuran indikator kualitas tanah menghasilkan indeks kualitas tanah. Indeks kualitas tanah merupakan indeks yang dihitung berdasarkan nilai dan bobot tiap indikator kualitas tanah. Indikator-indikator kualitas tanah dipilih dari sifat-sifat yang menunjukkan kapasitas fungsi tanah. Indikator kinerja tanah yang mencakup sifat fisik, kimia, dan biologi tanah oleh Gugino et al., (2009) tidak secara mutlak harus digunakan seluruhnya dalam penilaian kesehatan tanah.

Pengembangan indikator dilakukan untuk mengatasi permasalahan yang dapat menurunkan kualitas tanah, produktivitas tanaman, dan keuntungan secara finansial. Penyebab penurunan kualitas tanah seperti pemadatan tanah, retakan permukaan, peningkatan tekanan hama dan penyakit, gulma, rendahnya berat jenis tanah dan rendahnya keanekaragaman organisme menguntungkan dalam tanah.Mengacu pada kemampuan tanah pada lahan pertanian untuk tetap berproduksi. Pemanfaatan tanah secara terus menerus menyebabkan tren negatif pada produksi yang berke- lanjutan. Pada skala petani, pola pertanian berlanjut dinilai tepat dalam sistem pertanian. Selain skala keberkelanjutan, faktor dinamis yang bergantung pada waktu dan permintaan akan hasil pertanian.

Lahan kering selalu dikaitkan dengan pengertian bentuk - bentuk usahatani bukan sawah yang dilakukan oleh masyarakat di bagian hulu suatu daerah aliran sungai (DAS) sebagai lahan atas (upland) atau lahan yang terdapat di wilayah kering (kekurangan air) yang tergantung pada air hujan sebagai sumber air (Manuwoto, 1991). Dengan luas 61,53 juta ha lahan kering yang sesuai untuk pertanian (Tabel 1) pemanfaatan lahan kering untuk pertanian sering diabaikan oleh para pengambil kebijakan, yang lebih tertarik pada peningkatan produksi beras pada lahan sawah. Hal ini mungkin karena ada anggapan bahwa meningkatkan produksi padi sawah lebih mudah dan lebih menjanjikan dibanding padi gogo yang memiliki risiko kegagalan lebih tinggi. Padahal lahan kering tersedia cukup luas dan berpotensi untuk menghasilkan padi gogo $>5 \mathrm{t} / \mathrm{ha}$. Lahan kering yang potensial dapat menghasilkan bahan pangan yang cukup dan bervariasi, tidak hanya padi gogo tetapi juga bahan pangan lainnya, bila dikelola dengan menggunakan teknologi yang efektif dan strategi pengembangan yang tepat. (Abdurachman, 2008).

Optimalisasi penggunaan lahan kering untuk pertanian dapat dilakukan dengan analisis indeks kualitas tanah. Analisis indeks kualitas tanah berfungsi untuk menguraikan berbagai faktor pembatas di lahan kering yang berhubungan dengan fungsi tanah. Indeks kualitas tanah dihitung berdasarkan analisis Minimum Data Set (MDS). Sehingga penyelidikan tersebut diharapkan faktor pembatas dapat ditang- gulangi dengan berbagai masukan dan arahan untuk pengolahan lahan kering di Desa Ngalang, Gedangsari, Kabupaten Gunungkidul dimasa yang akan datang. 


\section{METODE PENELITIAN}

Penelitian ini dilaksanakan mengunakan metode survei lapangan yaitu metode pengumpulan data untuk men- dapatkan keterangan dengan melakukan peninjauan serta pengamatan langsung di lapangan yang merupakan tempat/ lokasi penelitian. Subyek penelitian adalah Desa Ngalang dengan luas 1481,71 ha. Dengan areal Ngalang Selatan yang diamati dengan luasan 640,39 ha. Penentuan titik yang diamati dengan ketentuan pada areal datar hingga agak curam saja yang di teliti kondisi kualitas tanahnya. Dengan pertimbangan, petani pada areal lahan kering umumnya tidak memiliki modal yang cukup, sedangkan pengolahan lahan pada relief curam diperlukan pembuatan teras bangku dan peng- usahaan irigasi yang tergolong sulit (Pirngadi dan Karim, 2006). Sehingga dilakukan penelitian introduksi pada kawasan dengan relief datar hingga agak curam. Pengambilan contoh tanah dilakukan secara komposit pada lapisan olah tanah (kedalaman $0-25 \mathrm{~cm}$ ). Contoh tanah dikering anginkan selama satu minggu kemudian dipersiapkan untuk keperluan analisis laboratorium. Pengambilan sampel tanah dilakukan dengan metode purposif yaitu penetuan pengambilan sampel pada lokasi yang telah di tentukan berdasarkan Peta Satuan Lahan (PSL). PSL diperoleh dari overlay (tumpang susun) peta kemi- ringan lahan, peta penggunaan lahan serta peta jenis tanah Desa Ngalang dengan menggunakan bantuan software ArcGIS 10.2 pada berbagai areal lahan kering yang ada di Desa Ngalang. Selanjutnya, kualitas tanah dinilai dengan menghitung Indeks Kualitas Tanah (IKT) berdasarkan MDS yang telah ditetapkan. Pada indikator yang dihitung memiliki indeks bobot. Selan- jutnya, indeks tersebut dikalikan dengan hasil parameter yang telah ditentukan nilai relatifnya dengan persamaan regresi. Sehingga didapatkan nilai (IKT) untuk satu indikator yang diamati. Akumulasi nilai IKT dari masing-masing fungsi tanah merupakan penggambaran relatif mengenai kondisi kualitas tanah yang teramati. Penentuan kelas kualitas tanah dari indikator kinerja tanah yang telah dihasilkan sehingga kelas kualitas tanah di Desa Ngalang dapat di inter- pretasikan.

Parameteryang diukur di lapangan, meliputi: Jeluk perakaran dan panjang lereng dengan meteran sedangkan kemiringan lereng menggunakan abney level. Analisis tanah di laboratorium untuk mengetahui parameter sifat fisik dan kimia tanah, meliputi: Berat volume (BV) dengan metode bongkahan, berat jenis (BJ) dengan metode piknometer, porositas tanah didapatkan dengan perhitungan, persentase debu dan lempung dengan metode pemipetan, $\mathrm{pH}$ aktual dengan $\mathrm{pH}$ meter, kadar $\mathrm{C}$ - organik menggunakan metode Walkey and Black, kadar $\mathrm{N}$ - total menggunakan metode Kjeldahl, kandungan $\mathrm{P}$ - tersedia menggunakan metode Bray dan kadar $\mathrm{K}$ - tersedia menggunakan metode Morgan Wolf.

Berdasarkan parameter yang dia- mati di atas. Indeks Kualitas Tanah dihitung berdasarkan kriteria Mausbach dan Seybold (1998), yang disesuaikan dengan kondisi lapangan menggunakan analisis Minimum Data Set (MDS). Perubahan yang dilakukan pada beberapa hal yaitu:

1. Fungsi filter dan buffering diubah dengan fungsi struktural penyangga dengan pertimbangan analisis MDS menyesuaikan kondisi wilayah Desa Ngalang yang cenderung berbukit - bukit.

2. Indikator Posisi Lereng diubah menjadi Faktor Lereng dengan pertimbangan bahwa faktor lereng dapat diukur dari panjang dengan kemiringan lereng. Apabila nilai faktor lereng semakin besar mengindikasikan menurunnya infil- trasi tanah, ketersediaan air tanah, dan meningkatnya laju air limpasan 
3. Indikator kemantapan agregat didekati dengan presentase debu + lempung. Presentase debu + lempung sangat menentukan keman- tapan agregat yang dapat berperan pada fungsi pengaturan kelengas- an, penyaring dan penyangga tanah.

4. Indikator $\mathrm{C}$ total maupun indikator biologis lainnya dapat diganti dengan $\mathrm{C}$ organik, dengan pertim- bangan bahwa pengukuran $\mathrm{C}$ - organik lebih mudah dilakukan.

5. Batas atas dan batas bawah serta contoh fungsi penilaian untuk beberapa indikator tanah diturunkan atau dinaikkan, disesuaikan dengan hasil pengukuran para- meter di lapangan.

Modifikasi tersebut terangkum dalam Tabel 3. Pada halaman berikutnya. Cara perhitungan indeks adalah sebagai berikut:

1. Indeks penilaian terdiri dari 3 indeks bobot dasar, dimana indeks bobot kedua dan ketiga merupakan turunan dari indeks bobot yang pertama.

2. Indeks bobot dihitung dengan mengalikan bobot fungsi tanah (bobot 1) dengan bobot medium perakaran (bobot 2) dengan bobot jeluk perakaran (bobot 3). Misalnya, indeks bobot untuk porositas diperoleh dengan mengalikan 0,40 (bobot 1) dengan 0,33 (bobot 2) dengan 0,60 (bobot 3), dan hasilnya sama dengan 0,080.

3. Skor dihitung dengan mem- bandingkan data pengamatan dari indikator tanah dan fungsi penilaian. Skor berkisar dari nol (0) untuk kondisi buruk dan satu (1) untuk kondisi baik. Penetapan skor dapat melalui interpolasi atau persamaan linier sesuai dengan kisaran yang ditetapkan berdasar harkat atau berdasarkan data yang diperoleh.

4. Fungsi penilaian berdasarkan batas atas dan batas bawah dari hasilpengamatan atau dapat melihat dari contoh penilaian fungsi oleh Karlen et al., (1994).

Apabila hasil pengamatan memiliki nilai yang lebih rendah dibandingkan batas bawah fungsi penilaian maka hasil pengamatan tersebut ditetapkan menjadi batas bawah penilaian dan berlakupula pada sebaliknya.

1. Indeks kualitas tanah dihitung dengan mengalikan indeks bobot dan skor dari indikator

2. Indeks dari masing - masing indikator di jumlah. Nilai total dari indeks diklasifikasikan kedalam Indeks kualitas tanah (Tabel 1).

Tabel 1. Kriteria penilaian tanah berdasarkan indikator kinerja

\begin{tabular}{ccc}
\hline No & Kelas Nilai IKT $\left.^{*}\right)$ & Kriteria Kualitas Tanah \\
\hline 1 & $0,80-1,00$ & Sangat Baik \\
2 & $0,60-0,79$ & Baik \\
3 & $0,40-0.59$ & Sedang \\
4 & $0,20-0,39$ & Buruk \\
5 & $0,00-0,19$ & Sangat Buruk \\
\hline
\end{tabular}

${ }^{\left.{ }^{7}\right)}$ IKT = Indeks Kualitas Tanah 


\section{HASIL DAN PEMBAHASAN}

Indeks kualitas tanah dapat dilakukan melalui pengamatan tanah secara dinamis melalui fungsi fungsi tanah di Desa Ngalang Kecamatan Gedangsari, Gunung kidul Kualitas tanah sebagai berikut: Perhitungan indeks kualitas tanah di Desa Ngalang, didominansi kualitas tanah sedang. Namun pada satuan lahan sawah tadah hujan memiliki nilai indeks yang lebih besar dibandingkan dengan satuan lahan tegalan. Hal tersebut dikarenakan pada sawah tadah hujan memiliki pematang yang dapat menahan air saat musim penghujan tiba, sehingga untuk fungsi pengaturan dan penyaluran air pada satuan lahan sawah tadah hujan memiliki bobot yang lebih tinggi bila dibandingkan dengan lahan tegalan. Pada jenis lahan dengan jenis Tanah Inceptisol juga memiliki nilai yang lebih tinggi bila dibandingkan dengan Regosol. Hal tersebut dikarenakan pada Inceptisol fraksi pasir telah termineralisasi ke fraksi yang lebih kecil. Sehingga, koloid anorganik yang terbentuk menjadi lebih banyak bila dibandingkan dengan satuan lahan dengan jenis Regosol. Akumulasi koloid anorganik yang lebih tinggi berdampak pada meningkatnya kapasitas pertukaran kation tanah, sehingga kesuburan tanahnya juga meningkat.

Kualitas tanah terbaik terletak pada Sawah Tadah Hujan Inceptisol Agak Curam, sedangkan kualitas tanah terburuk pada Tegalan Entisol Agak Curam. Lahan dengan kualitas baik pada satuan lahan Sawah Tadah Hujan Inceptisol Agak Curam, pola pengelolaan dapat dipertahankan karena sudah memiliki kualitas tanah yang baik. Lahan dengan kualitas sedang pada satuan lahan $\mathrm{TE}_{1}$ (Tegalan Entisol Landai), $\mathrm{TI}_{1}$ (Tegalan Inceptisol Landai), TI2 (Tegalan Inceptisol Agak Curam), SE1 (Sawah Tadah Hujan Entisol Landai), SE2 (Sawah Tadah Hujan Entisol Agak Curam), dan SI 1 (Sawah Tadah Hujan Inceptisol Landai), pola pengelolaan dapat ditingkatkan pada bagian keharaan meliputi unsur $\mathrm{N}, \mathrm{P}$ dan $\mathrm{K}$ serta menjaga nilai $\mathrm{pH}$ tanah tetap stabil pada kisaran 6,5. Lahan dengan kualitas buruk pada satuan lahan TE2 (Tegalan Entisol Agak Curam), pola pengelolaan lahan diperlukan upaya pengolahan tanah serta penambahan bahan organik dengan tujuan meningkatnya keter- sediaan air yang terikat oleh pori tanah dan meningkatnya kadar hara pada satuan lahan.

\section{KESIMPULAN}

Analisis kualitas tanah lahan kering pada berbagai penggunaan lahan di Desa Ngalang, Kecamatan Gedangsari, Kabupaten Gunungkidul dapat ditarik kesimpulan sebagai berikut:

1. Indeks Kualitas Tanah (IKT) di Desa Ngalang, Kecamatan Gedangsari, Gunungkidul mempunyai kriteria kualitas buruk seluas 63,05 ha $(9,85 \%)$ dari luas areal yang diamati yakni pada satuan lahan $\mathrm{TE}_{2}$ (Tegalan Entisol Agak Curam); Kriteria sedang 523,9 ha $(81,81 \%)$ dari luas areal yang diamati yakni pada satuan lahan $\mathrm{TE}_{1}$ (Tegalan Entisol Landai), $\mathrm{TI}_{1}$ (Tegalan Inceptisol Landai), $\mathrm{TI}_{2}$ (Tegalan Inceptisol Agak Curam), SE1 (Sawah Tadah Hujan Entisol Landai), SE2 (Sawah Tadah Hujan Entisol Agak Curam), dan SI 1 (Sawah Tadah Hujan Inceptisol Landai); dan kriteria baik 53,44 ha $(8,34 \%)$ dari luas areal yang diamati yakni pada satuan lahan SI2 (Sawah Tadah Hujan Inceptisol Agak Curam).

2. Indeks Kualitas Tanah (IKT) Desa Ngalang Kecamatan Gedangsari, Gunungkidul pada berbagai penggunaan lahan termasuk dalam kriteria sedang. 


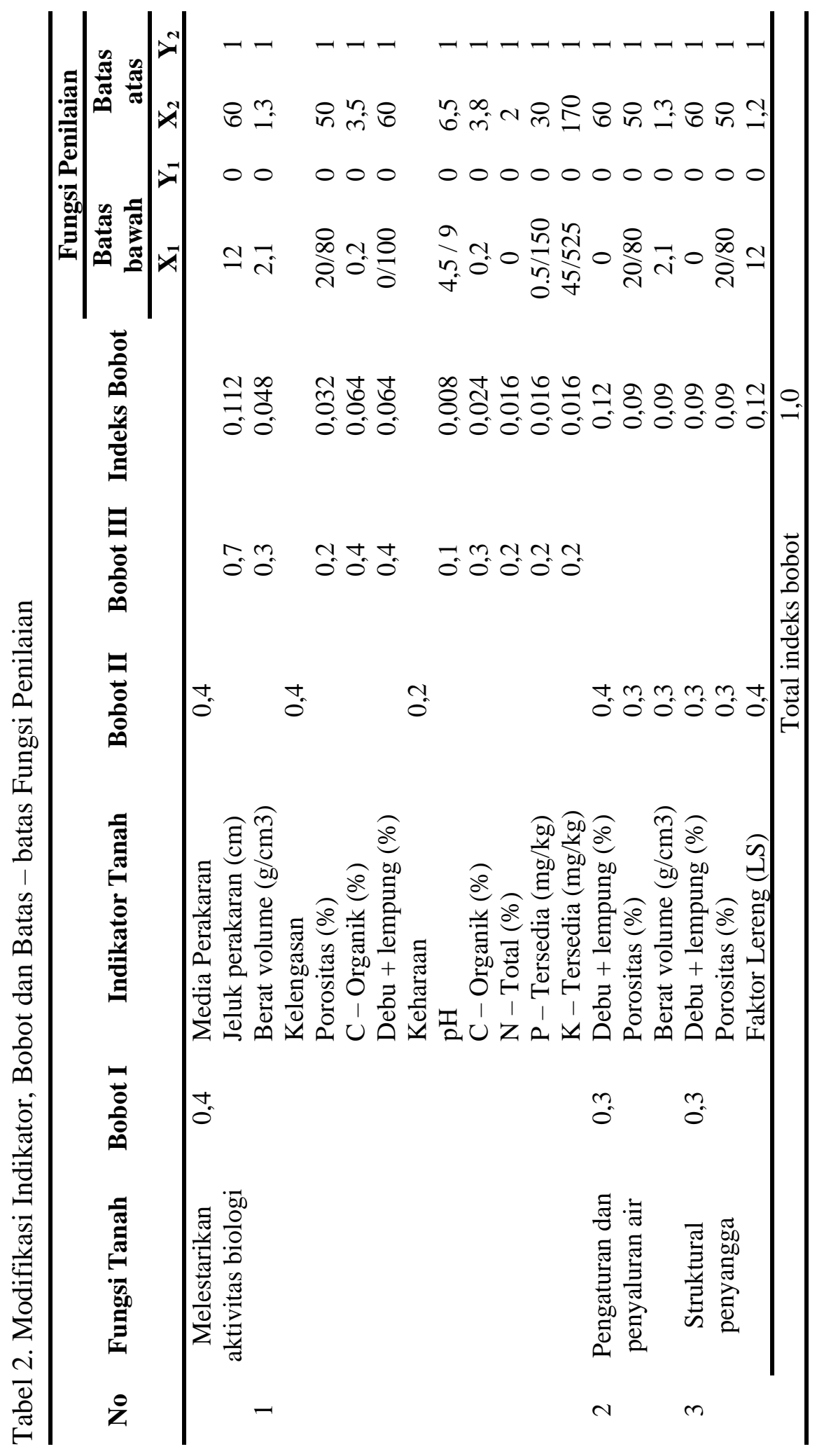




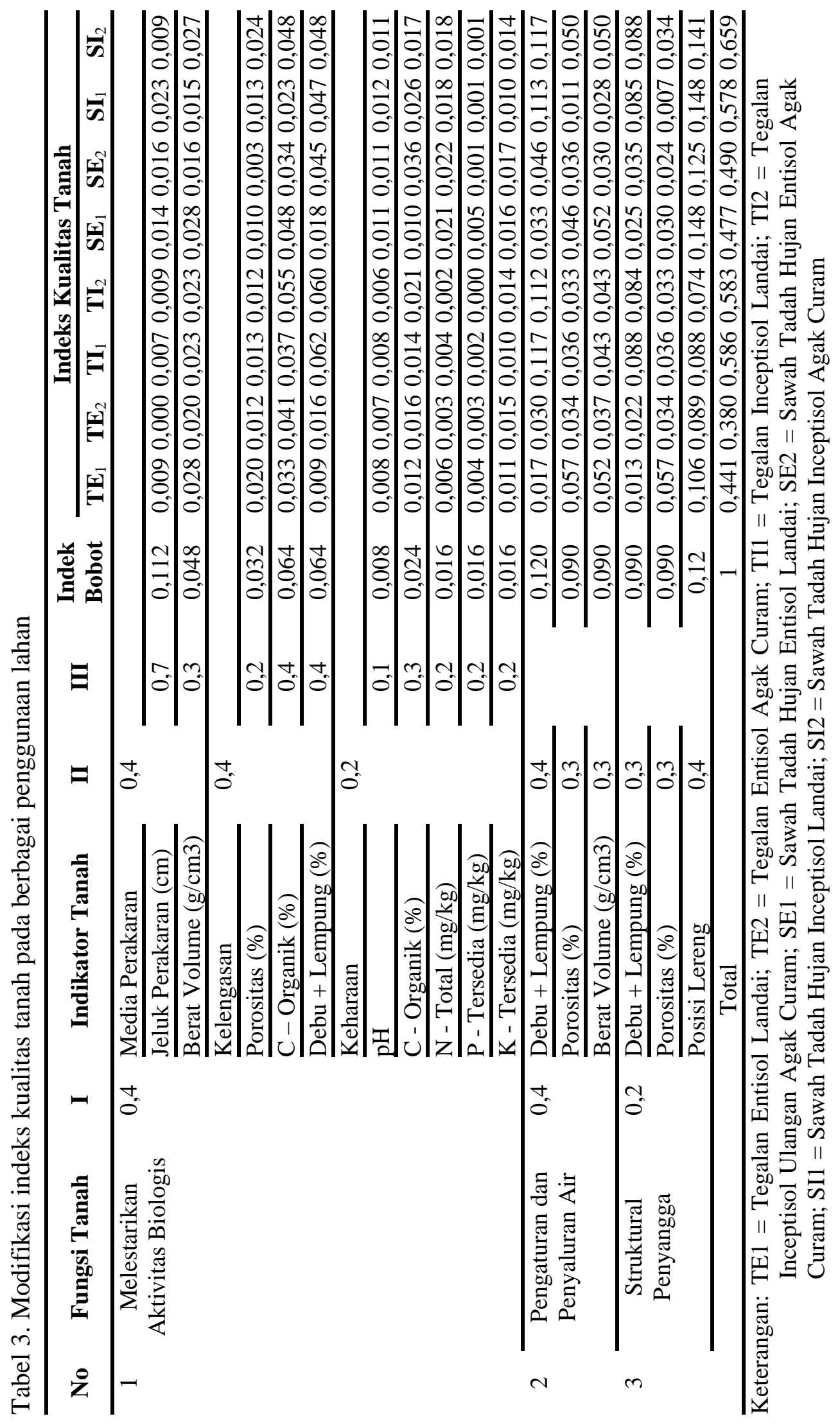




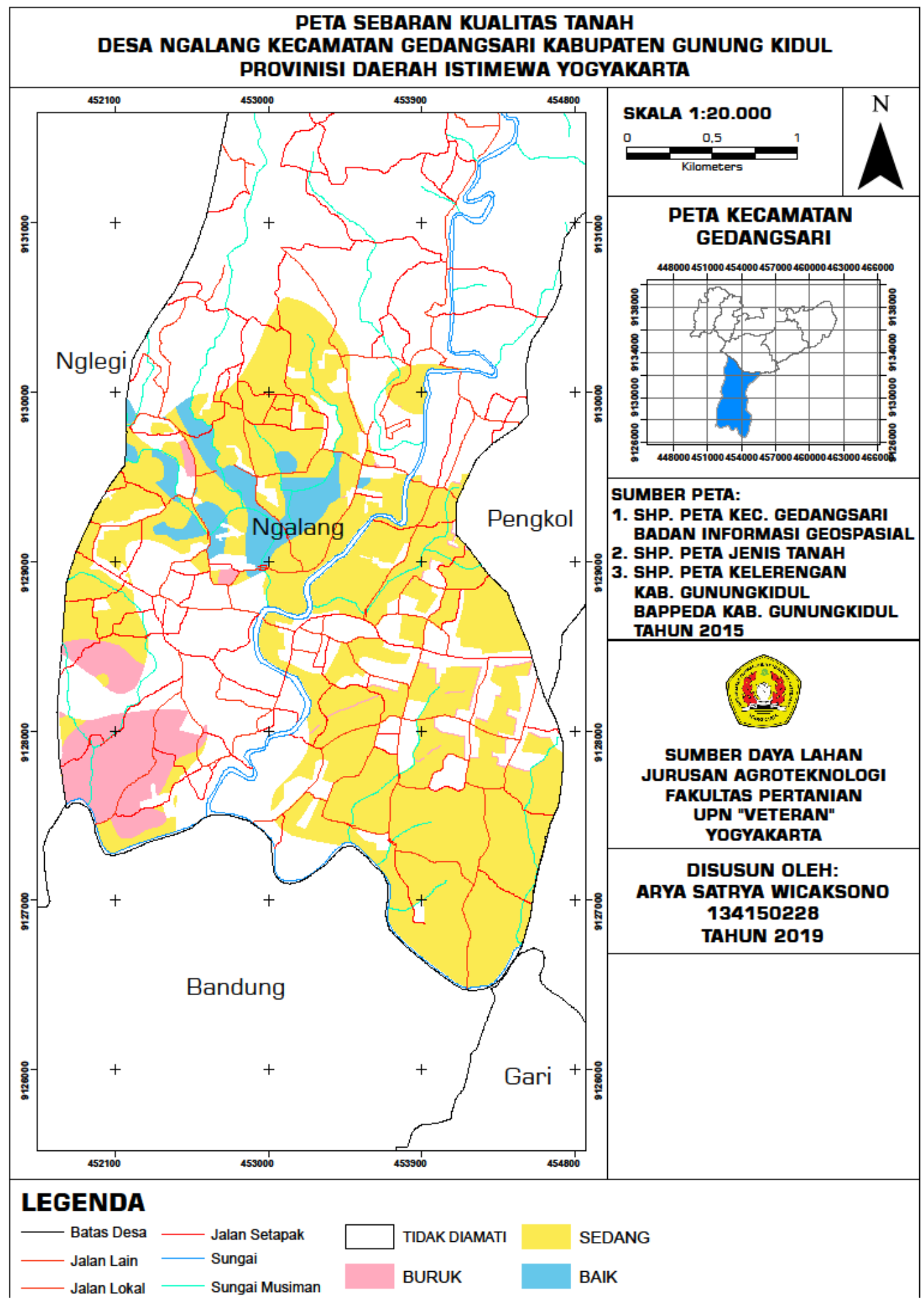

Gambar 1. Peta sebaran kualitas tanah Desa Ngalang Kecamatan Gedangsari, Gunungkidul Yogyakarta 


\section{DAFTAR PUSTAKA}

Abdurachman, A., Dariah A., dan Mulyani A. 2008. Strategi dan Teknologi Pengelolaan Lahan Kering Mendukung Pengadaan Pangan Nasional. Jurnal Litbang Pertanian, 27 (2).

Arifin, Z. 2011. Analisis Indeks Kualitas Tanah Entisol pada Berbagai Penggunaan Lahan yang Berbeda. Agroteksos 21 (1) 47 - 54. April 2011. Fakultas Pertanian Unram.

Badan Pusat Statistik. 2005. Statistik Indonesia. Badan Pusat Statistik Indonesia. Jakarta 2010. Statistik Indonesia. Badan Pusat Statistik Indonesia. Jakarta

Balitsa. 2014. Sayuran Melimpah di Lahan Tadah Hujan dengan Air Embung. Badan Litbang Pertanian. Lembang

Balittanah. 2006. Sifat Fisik Tanah dan Analisisnya. Balai Besar Litbang Sumberdaya Lahan Pertanian. Bogor 2009. Petunjuk Teknis Analisis Kimia Tanah, Tanaman, Air, dan Pupuk. Balai Besar Litbang Sumberdaya Lahan Pertanian. Bogor . 2014. Konservasi Tanah Menghadapi Perubahan Iklim. Balai Besar Litbang Sumberdaya Lahan Pertanian. Bogor

Bappeda Kabupaten Gunungkidul. 2005. Triple a Atlas Gunungkidul. Badan Perencana Pembangunan Daerah. Yogyakarta 2018. Kecamatan Gedangsari dalam Angka 2018. Badan Perencana Pembangunan Daerah. Yogyakarta

Billy, B. 1981. Water Harvesting for Dryland and Floodwater Farming on The Navajo Indian Reservation. Dalam: Notohadiprawiro. 1989. Pertanian Lahan Kering Di Indonesia: Potensi, Prospek, Kendala dan Pengembangannya. Lokakarya Evaluasi Pelaksanaan Proyek Pengembangan Palawija. USAID. Bogor

Damanik, M., M., B., Hasibuan., Fauzi, B.E., Sarifuddin., dan Hanum, H. 2010. Kesuburan Tanah dan Pemupukan. USU Press: Medan.

Darmawijaya, M. I., 1990. Klasifikasi Tanah. Dasar Teori Bagi Peneliti Tanah dan Pelaksanaan Pertanian di Indonesia. UGM Press. Yogyakarta.

Doran, J., W. \& T., B. Parkin, 1994. Defining and Assessing Soil Quality, In Defining Soil Quality for a Sustainable Environment. JW. Doran, DC. Coleman, DF. Bezdicek, \& BA. Stewart (eds). SSSA Spec. Pub. No. 35. Soil Sci. Soc. Am., Am. Soc. Agron., Madison, WI, pp.3-21. Gugino, B.K., Idowu, O.J. Schindelbeck, R.R., van Es, H.M., Wolfe, D.W., Thies, J.E., dan Abawi, G.S. 2009. Cornell Soil Health Assessment Training Manual, Edition 1.2, Cornell University, Geneva, N.Y 59 pp.

Fahmi, A., Syamsudin, Sri N., H., U., dan Bostang R. 2010. Pengaruh Interaksi Hara Nitrogen dan Fosfor terhadap Pertumbuhan Tanaman Jagung (Zea Mays L.) pada Tanah Regosol dan Latosol. Berita Biologi 10(3), Desember 2010

Gugino, B., K., Idowu, O., J., Schindelbeck, R.R., van Es, H.M., Wolfe, D.W., Thies, J.E., dan Abawi, G.S. 2009. Cornell Soil Health Assessment Training Manual, Edition 1.2, Cornell University, Geneva, N.Y 59 pp.

Hanafiah, K., A. 2014. Dasar-dasar Ilmu Tanah. Rajawali Pers. Jakarta.

Handoko. 1995. Klimatologi Dasar. Bogor: Pustaka Jaya.

Hardjowigeno, S. 2013. Ilmu Tanah. Akademika Pressindo. Jakarta

Ivezic, Vladmir. 2015. Trace Metal Availability and Soil Quality Index Relationships under Different Land Uses. Soil Science Society of America Journal. 
doi:10.2136/sssaj2015.03.012

Juarti. 2016. Analisis Indeks Kualitas Tanah Andisol pada Berbagai Penggunaan Lahan di Desa Sumber Brantas Kota Batu. Jurnal Pendidikan Geografi 21 (2) 58 - 71. Juni 2016

Karlen, D., L., Wollenhaupt, N., C., Erbach, D., C., Berry, E., C., Swan, J., B. 1994. Long - Term Tillage Effect on Soil Quality. Dalam: Lal, R. 1998. Soil Quality and Agricultural Sustainability. Ann Arbor Press: Chelsea, Michigan United States of America

Kartasapoetra, A., G. 1987. Teknologi Konservasi Tanah dan Air. PT Rineka Cipta, Jakarta.

Kartono H., Rahardjo S., Sandy I., M. 1989. Esensi Pembangunan Wilayah dan Penggunaan Tanah Berencana. Penerbit Geografi Fakultas MIPA. Universitas Indonesia. Jakarta.

Laishram J., Saxena K., G., Maikhuri R., K., Rao K., S. 2012. Soil Quality and Soil Health: A Review. International Journal of Ecology and Environmental Sciences 38 (1): 19-37, 2012. National Institute of Ecology, New Delhi

Lal, R. 1994. Method and Guidelines for Assessing Sustainable Use for Soil and Water Resources in the Tropics. SMSS Tech. Monograph no. 21. USDA. 78 p. Dalam: Balittanah. 2014. Konservasi Tanah Menghadapi Perubahan Iklim. Balai Besar Litbang Sumberdaya Lahan Pertanian. Bogor 1998. Soil Quality and Agricultural Sustainability. Ann Arbor Press: Chelsea, Michigan United States of America

Made, S., I. 1995. Tanah, Muka Bumi. Indograph Bakti. FMIPA Universitas Indonesia. Manuwoto. 1991. Peranan Pertanian Lahan Kering di dalam Pembangunan Daerah. Simposium Nasional Penelitian dan Pengembangan Sistem Usahatani Lahan Kering yang Berkelanjutan. Malang 29-31 Agustus 1991.

Minardi. 2009. Optimalisasi Pengelolaan Lahan Kering untuk Pengembangan Pertanian Tanaman Pangan. Dalam: Pidato Pengukuhan Guru Besar Ilmu Tanah. Sidang Senat Terbuka Universitas Sebelas Maret. 26 Febuari 2009. Surakarta

Moebius - Clune, B. N., Moebius-Clune, D. J., Gugino, B. K., Idowu, O. J., Schindelbeck, R. R., Ristow, A. J., vas Es, H. M., Thies, J. E., Shayler, H. A., McBride, M. B., Kurtz, K. S. M., Wolfe, D. W., dan Abawi G. S. 2017. Comprehensive Assessment of Soil Health, Third Edition. New York: Cornell University.

Munir, M. 1996. Tanah-Tanah Utama Indonesia. Dunia Pustaka Jaya, Jakarta.

Mustafa. 2012. Dasar - Dasar Ilmu Tanah. Makassar: Universitas Hassanudin

Notohadiprawiro, T. 1989. Pertanian Lahan Kering Di Indonesia: Potensi, Prospek,

Kendala dan Pengembangannya. Lokakarya Evaluasi Pelaksanaan Proyek Pengembangan Palawija. USAID. Bogor 1999. Tanah dan Lingkungan. Direktoran Jendral Pendidikan Tinggi. Departemen Pendidikan dan Kebudayaan

NRCS (Natural Resources Conservation Service). 1996. Indicators for Soil Quality Evaluation. http://soils.usda.gov/sqi/publications/files/sq-2.pdf

Partoyo. 2005. Analisis Indeks Kualitas Tanah Pertanian di Lahan Pasir Pantai Samas Yogyakarta. Jurnal Ilmu Pertanian 12 (2): 140 - 151.

Pirngadi K., dan Karim A., M. 2006. Peningkatan Produktivitas Padi pada Lahan Sawah Tadah Hujan melalui Pengelolaan Tanaman Terpadu. Jurnal Penelitian 
Pertanian Tanaman Pangan 25 (2): 116 - 123.

Riwandi. 2007. Kualitas Tanah. Bahan Ajar Program Studi Ilmu Tanah Jurusan Budidaya Pertanian Fakultas Pertanian UNIB

Seybold, C., A., Mausbach M., J., Karlen D., L., dan Rogers H., H. 1996. Quantification of Soil Quality. Adv. Soil Science

SSSA (Soil Science Society of America). Glossary of Soil Science Terms. SSSA, Madison, WI, 1987. Dalam: Karlen D., L., Susan S., A., Brian J., W., dan Ted M., Z. 2008. Soil Quality Assesment: Past, Present and Future. Electronic Journal of Intergrative Bioscences 6 (1): 3 - 14. 29 Desember 2008

Subagyo. 1970. Dasar - Dasar Ilmu Tanah. PT Soeroengan: Jakarta

Subagyo H., N. Suharta, dan Siswanto A. B.. 2000. Tanah - tanah Pertanian di Indonesia. Dalam: (Tim Puslittanak, eds.) Sumber Daya Lahan Indonesia dan Pengelolaannya. Puslittanak. p: $21-65$

Subowo, G. 2012. Pemberdayaan Sumberdaya Hayati Tanah untuk Rehabilitasi Tanah Ultisol Terdegradasi. Jurnal Sumberdaya Lahan 6 (2). Desember 2012

Thorn K.,A., dan Mikita M., A. 2000. Nitrite Fixation by Humic Substances. Soil Science Society of America Journal 64: 568-582.

USDA (United States Department of Agriculture). 2001. Guidelines for Soil Quality Assesment in Conservation Planning. Natural Resources Conservation Service Soil Quality Institute Washington, DC SQI-NRCS

Van Zuidam, R. A. 1985. Aerial Photo - Interpretation in Terrain Analysis and Geomorphologic Mapping. Dalam: Cahyadi, H., Iqbal J., Edi, T., dan Ismawan. 2016. Geomorphology Characteristic of Ciangsana and Surrounding Areas, Cikembar Sub - District, Sukabumi Regency, West Java. Proceeding, Seminar Nasional Kebumian $\mathrm{Ke}-9$. 